\title{
cAMP inhibits natriuretic peptide receptor-B activity and increases C-type natriuretic peptide in FRTL-5 rat thyroid cells
}

\author{
D F Sellitti, E Puggina ${ }^{1}$, C Lagranha ${ }^{2}$ and S Q Doi \\ Department of Medicine, Endocrinology and Nephrology Divisions, Uniformed Services University of the Health Sciences, Bethesda, Maryland 20814-4799, \\ USA \\ ${ }^{1}$ Methodist University of Piracicaba, Piracicaba, Brazil 13,40091, Brazil \\ ${ }^{2}$ Department of Biophysics and Physiology, Division of Endocrinology, University of Sao Paulo, Sao Paulo, Brazil \\ (Requests for offprints should be addressed to D Sellitti; Email: dsellitti@usuhs.mil)
}

\begin{abstract}
C-type natriuretic peptide (CNP) and its cognate guanylyl cyclase receptor, the natriuretic peptide receptor $\mathrm{B}$ (NPR-B) together constitute a regulatory system that controls cell function via the generation of intracellular cyclic GMP. In this report we have examined the role of cAMP signaling in the regulation of CNP and NPR-B activity in the FRTL-5 rat thyroid follicular cell line. As had been observed earlier with TSH, the cAMP mimetic, dibutyryl cAMP (dbcAMP; $1 \mathrm{mM}$ ) induced a significant reduction in CNP-stimulated cGMP generation that was first apparent after $6 \mathrm{~h}$ of treatment. The inhibitory effect of dbcAMP on NPR-B was dose dependent, with an $\mathrm{EC}_{50}$ of $0 \cdot 2 \mathrm{mM}$.

Pretreatment of FRTL-5 cells with either of two protein kinase A (PKA) inhibitors, KT-5720 and H-89, failed to curtail the dbcAMP reduction in NPR-B activity, suggesting that the cAMP pathway leading to inhibition of NPR-B is PKA independent. Whereas either a 30-min or a 24-h treatment with the protein kinase $\mathrm{C}$-activator phorbol myristate acetate failed to alter maximal levels of CNP-stimulated cGMP, a 24-h exposure to the calcium ionophore A23187 reduced CNP-stimulated
\end{abstract}

cGMP to about one-third of control. Pretreatment of FRTL-5 cells with the cell-permeable calcium chelator 1,2 bis(2-aminophenoxy)ethane- $\mathrm{N}, \mathrm{N}, \mathrm{N}^{1}, \mathrm{~N}^{1}$-tetraacetic acid, tetraacetoxymethyl ester completely abrogated the cAMP-induced reduction of CNP-stimulated cGMP. Real-time PCR showed no effect of dbcAMP on NPR-B transcript at 3 and $6 \mathrm{~h}$, but indicated a $40 \%$ reduction in transcript by dbcAMP at $24 \mathrm{~h}$. In contrast, real-time PCR indicated a 5-fold increase in CNP transcript at $3 \mathrm{~h}$, reaching 15.4-fold above control at $6 \mathrm{~h}$ in cells treated with dbcAMP. In addition, immunofluorescence staining of FRTL-5 cells with a specific antibody for CNP-22 showed the presence of cytoplasmic CNP that was upregulated by incubation with either TSH or dbcAMP.

These results suggested that cAMP signaling regulates the natriuretic peptide system in rat thyroid cells by increasing CNP expression, and reducing NPR-B activity. This latter action of cAMP appears to be both PKA independent and calcium dependent, and provides support for a dominant role for calcium in the regulation of NPR-B in the rat thyroid.

Journal of Endocrinology (2004) 180, 23-34

\section{Introduction}

The natriuretic peptides (atrial natriuretic factor (ANF), brain natriuretic peptide (BNP), and C-type natriuretic peptide (CNP)) constitute a small family of polypeptides that possess a 17-member disulfide ring as a common structural feature (Flynn 1997). Receptors for the natriuretic peptides (NPR) are of three distinct subtypes, two of which (NPR-A and NPR-B) are membraneassociated guanylyl cyclases that catalyze the conversion of GTP to cGMP upon hormone binding (Anand-Srivastava \& Trachte 1993, Potter \& Hunter 2001, Silberbach \& Rogers 2001). A third receptor subtype, NPR-C, shares considerable sequence homology with NPR-A and
NPR-B in its extracellular domain but does not possess an intracellular domain capable of cGMP production. Alternative signaling pathways have been proposed for this third NPR subtype (Levin 1993).

NPR-A mediates many of the effects of ANF and $\mathrm{BNP}$, circulating hormones released by myocardial cells in response to hormonal, metabolic, and mechanical stimuli that have potent natriuretic, diuretic, and vasorelaxant activities (Gardner et al. 1997). In contrast, NPR-B may be particularly important in the autocrine or paracrine control of cGMP production, as its principal ligand, CNP, does not circulate at high levels (Igaki et al. 1996), and is often produced by cells juxtaposed to cell types bearing the NPR-B receptor. Examples of such 'natriuretic peptide 
systems' are the vascular wall, in which CNP is produced by endothelium to control vascular smooth muscle contractility through NPR-B-generated cGMP (Suga et al. 1992), the ovarian follicle where CNP of extrafollicular origin activates NPR-B contained in granulosa cells (Noubani et al. 2000), and in bone where the CNP/ NPR-B pathway has been shown to be crucial in the process of endochondral ossification (Yasoda et al. 1998).

The hormonal regulation of NPR-B has been studied in several cell systems, including non-pigmented ciliary epithelial cells (Crook \& Chang 1997) and vascular smooth muscle cells (Abbey \& Potter 2002), where CNP stimulation of cGMP production has been shown to be inhibited by a number of hormones and locally acting substances (arginine vasopressin, histamine, angiotensin II and endothelin) that activate the phospholipase C/inositol phosphate/diacylglycerol phosphate signaling pathway. The mechanism underlying this inhibition of NPR-B has been suggested to involve the dephosphorylation of the receptor at a specific serine residue (Potter \& Hunter 2000).

The down-regulation of the guanylyl cyclase receptors NPR-A and NPR-B by receptor internalization and degradation has been controversial, with some groups suggesting that only NPR-C is internalized upon binding ligand (Pandey et al. 2002). However Pandey et al. (2002) have recently reported the ligand-regulated internalization and down-regulation of NPR-A in transfected human embryonic kidney 293 cells, suggesting that receptor endocytosis may be an important pathway for NPR-A and presumably NPR-B regulation in target cells.

Transcriptional regulation of NPR-B has also been demonstrated in certain cell types. Noubani et al. (2000) have shown that both estrogen (diethylstilbestrol) and gonadotropin (equine chorionic gonadotropin) result in an increase in NPR-B mRNA transcripts as determined by semiquantitative RT-PCR.

In previous studies with the FRTL-5 cell line, a continuous cell line derived from rat thyroid follicular cells, we have shown that NPR-B activity is regulated by thyrotropin (thyroid-stimulating hormone; TSH), with significant decreases in CNP-stimulated cGMP accumulation occurring following treatment with $1 \mathrm{mIU}$ bovine TSH compared with control (Sellitti \& Doi 1999). Although TSH signaling through the TSH receptor (TSH-R) has been shown to proceed down several different signaling pathways (including phospholipase $\mathrm{C} /$ inositol triphosphate/diacylglycerol), we speculated that the inhibitory effect of TSH on NPR-B activity is due principally to the coupling of TSH-R to adenylyl cyclase and the production of intracellular cAMP, since this is the primary signaling pathway for the TSH-R (Rapoport \& Spaulding 1996). A role for cAMP signaling in the regulation of NPR-B is of considerable interest in natriuretic peptide systems whose function is regulated by glycoprotein or modified amine hormones coupled to adenylyl cyclase via trimeric $G$ proteins. Such systems include both the thyroid and vascular natriuretic peptide systems, where elevations in cAMP have been shown to down-regulate the other cGMP-producing pathway in smooth muscle cells, nitric oxide (NO)/soluble guanylyl cyclase (Papapetrapoulos et al. 1995).

In the present report, we have tested the hypothesis that cAMP generation underlies the previously reported inhibition of NPR-B activity by TSH, and we examine the mechanism by which this down-regulation occurs.

\section{Materials and Methods}

\section{Reagents}

Rat ANF (ANF-(99-126)) and CNP-22 were purchased from Peninsula Laboratories, Inc. (Belmont, CA, USA). TSH from bovine pituitary (2 IU/mg protein), $\mathrm{N}^{6}, 2^{\prime}-\mathrm{O}-$ dibutyryladenosine $3^{\prime}, 5^{\prime}$-cyclic monophosphate sodium salt $(\mathrm{Bu}) 2$ cAMP, phorbol 12-myristate 13-acetate (PMA), and 1,2 bis(2-aminophenoxy)ethane- $\mathrm{N}, \mathrm{N}, \mathrm{N}^{1}, \mathrm{~N}^{1}$ tetraacetic acid, tetraacetoxymethyl ester (BAPTA-AM) were purchased from Sigma Chemical Co. (St Louis, MO, USA). A23187 (free acid), KT-5720, and H-89 were obtained from Calbiochem-Novabiochem Corp. (La Jolla, CA, USA).

\section{Cell culture}

FRTL-5 cells (American Type Culture Collection, Manassas, VA, USA; ATCC CRL 8305 F1 subclone) were obtained originally from Dr Leonard Kohn (University of Ohio, Athens, OH, USA). Cells were grown in 6H medium (Coon's modified Ham's F-12 medium (Sigma Chemical Co.) supplemented with 5\% calf serum (Cambrex, Walkersville, MD, USA), $1 \mathrm{mM}$ non-essential amino acids (Cambrex), and a six hormone mixture (TSH, insulin, somatostatin, hydrocortisone, transferrin, and glycyl-histidyl-lysine)) as previously described (Ambesi-Impiombato et al. 1982). Cells were also maintained in $5 \mathrm{H}$ medium, identical to the above except for the absence of TSH. All studies were performed on confluent, non-proliferating cell populations.

\section{cGMP assay}

FRTL-5 cells were grown to confluence in Coon's 6H medium $(1 \mathrm{mU} / \mathrm{ml} \mathrm{TSH})$ in 24 -well plates and, after washing, were equilibrated in $5 \mathrm{H}$ medium for at least 3 days before adding treatment medium consisting of $5 \mathrm{H}$ medium and various reagents. At assay, treatment medium was aspirated, and culture wells received $0.4 \mathrm{ml}$ assay medium containing $1 \mathrm{mM} \mathrm{CaCl}, 1 \mathrm{mM} \mathrm{MgSO} 4,1 \%$ bovine serum albumin, $0.5 \mathrm{mM}$ isobutylmethylxanthine (IBMX), and CNP $(0-1 \mu \mathrm{M})$. After a 20 -min incubation at $37^{\circ} \mathrm{C}$, medium was aspirated, wells received $0.5 \mathrm{ml}$ of 
a $0 \cdot 1 \mathrm{M} \mathrm{HCl}$ solution containing $0.1 \mathrm{mM} \mathrm{CaCl}_{2}$, and these samples were stored at $-70{ }^{\circ} \mathrm{C}$ for determination of cGMP content by radioimmunoassay (Biomedical Technologies, Staughton, MA, USA). All samples were diluted 1:5 in acetate buffer and acetylated before being assayed. Maximal cGMP accumulation and $\mathrm{EC}_{50}$ were determined by sigmoid fit to cGMP generation data using GraphPad Prism software (GraphPad, San Diego, CA, USA).

\section{$R N A$ extraction and real-time PCR}

FRTL-5 cells grown in 6-well culture dishes were homogenized and total RNA was extracted using the RNAeasy mini kit (Qiagen, Valencia, CA, USA) following the manufacturer's protocol. A DNAse digestion step in this procedure assures the elimination of DNA contamination of the final PCR assay. Total RNA concentrations of the samples were determined by measuring absorbance at $260 \mathrm{~nm}$, and $100 \mathrm{ng}$ total RNA was used for reverse transcription (RT) and amplification of NPR-B cDNA using real-time PCR in the ABI Prism 7700 Sequence Detection System (Applied Biosystems, Foster City, CA, USA). TaqMan one-step RT-PCR master mix reagents were purchased from Applied Biosystems. Primers and 5'FAM-labeled probe for rat NPR-B, rat CNP, and rat $\beta$-actin were designed from National Center for Biotechnology Information (NCBI) GenBank sequences (accession numbers: NM 053838, rat NPR-B; NM 053750, rat CNP; and NM 031144, rat $\beta$-actin) using Primer Express, version 1.5 software (Applied Biosystems), and synthesized by Epoch Biosciences, San Diego, CA, USA. Primer and probe sequences for rat NPR-B are as follows: sense primer, TGAGCAAGCCACCCACTTC; antisense primer, CAGCGGGCCGCAGATA; probe, AGAGCC AACGGGCGCATTGTGT. Primers and probe for rat CNP are: sense primer, CAAGAAGGGCTTGTCCAA AGG; antisense primer, AACATCCCAGACCGCT CATG; probe, CCTCAAGCTGGACCGGATCGGC. Primers and probe for rat $\beta$-actin are: sense primer, TCTGTGTGGATTGGTGGCTCTA; antisense primer, CTGCTTGCTGATCCACATCTG; probe, CCTGGC CTCACTGTCCACCTTCCA. For NPR-B, reaction mix contained $0 \cdot 25 \mathrm{U} / \mu \mathrm{l}$ MultiScribe enzyme (Applied Biosystems), 0.4 U/ $\mu$ l RNAse inhibitor, $300 \mathrm{nM}$ sense and antisense primer, $250 \mathrm{nM}$ probe and $100 \mathrm{ng}$ RNA in a total volume of $50 \mu \mathrm{l}$. Reaction mix for $\beta$-actin and for CNP was identical except for a TaqMan probe concentration of $150 \mathrm{~nm}$. Thermal cycling parameters for both primers were as follows: $48^{\circ} \mathrm{C}, 30 \mathrm{~min}$; $95^{\circ} \mathrm{C}, 10 \mathrm{~min}$; and 40 cycles of denaturing at $95^{\circ} \mathrm{C}$ for $15 \mathrm{~s}$, and annealing/extension for $1 \mathrm{~min}$ at $60^{\circ} \mathrm{C}$. Ct values were determined for both NPR-B and $\beta$-actin for each sample, and relative quantitation of NPR-B transcript was determined by the comparative threshold cycle $(\mathrm{Ct})$ method.

\section{Immunofluorescence studies}

FRTL-5 cells were plated onto round glass coverslips in 24-well plates in $6 \mathrm{H}$ medium and following either continued exposure to $6 \mathrm{H}$ medium or replacement of medium with $5 \mathrm{H}$ medium or $5 \mathrm{H}$ containing $1 \mathrm{mM}$ dibutyryl cAMP (dbcAMP) for an additional 3 days, were washed with phosphate-buffered saline (PBS) and fixed in cold methanol. Cells were then incubated with rabbit antibody to CNP-22 (Peninsula Laboratories, Inc.) at a dilution of 1:200 in PBS or rabbit antibody to human Tg (Dako, Carpinteria, CA, USA) at a dilution of 1:400 for $60 \mathrm{~min}$ at room temperature. Cells incubated without primary antibody served as a negative control. After being washed, cells were incubated with a 1:50 dilution of fluorescein-isothiocyanate-labeled goat anti-rabbit IgG (ICN, Irvine, CA, USA). The coverslips were washed and mounted on slides with glycergel (Dako), then observed and photographed with a microscope outfitted with a vertical epifluorescence unit.

\section{Data analysis}

The data from all CNP-stimulated cGMP studies were graphed and analyzed using Graph Pad Prism, and best-fit values were used to determine both the maximal level of cGMP production ('top') and the $\mathrm{EC}_{50}$ of cGMP production. In addition, Graph Pad Instat software was used to determine significant differences between treatment groups using one-way analysis of variance followed by a Tukey-Kramer multiple comparisons test. Significant differences between groups were considered to result in a $P$ value less than $0 \cdot 05$.

\section{Results}

\section{Effect of dbcAMP on cGMP production}

We have previously shown that NPR-B activity in FRTL-5 rat thyroid cells, assessed as CNP-stimulated cGMP production, is significantly inhibited by long-term treatment with TSH. To determine whether the inhibition of NPR-B occurs via the adenylyl cyclase/cAMP arm of TSH signaling, we repeated these studies using dbcAMP in place of TSH. Figure 1 compares CNPstimulated cGMP production in confluent cultures of FRTL-5 cells maintained in 5 $\mathrm{H}$ medium (control), or in $5 \mathrm{H}$ medium with the addition of $1 \mathrm{mM}$ dbcAMP for 4 days. As we had previously observed with TSH treatment, dbcAMP reduced the maximal level of CNP-stimulated cGMP from $26 \cdot 3$ to $2 \cdot 3 \mathrm{pM} / \mathrm{ml}$ in the example shown without significantly affecting the $\mathrm{EC}_{50}$ of the cGMP production $\left(\mathrm{EC}_{50}\right.$ control, $32 \mathrm{nM} ; \mathrm{EC}_{50}$ dbcAMP, $45 \mathrm{nM})$. Basal cGMP content, near the limits of detection of this assay, was unaffected by exposure to dbcAMP. These results suggested that activation of the adenylyl 


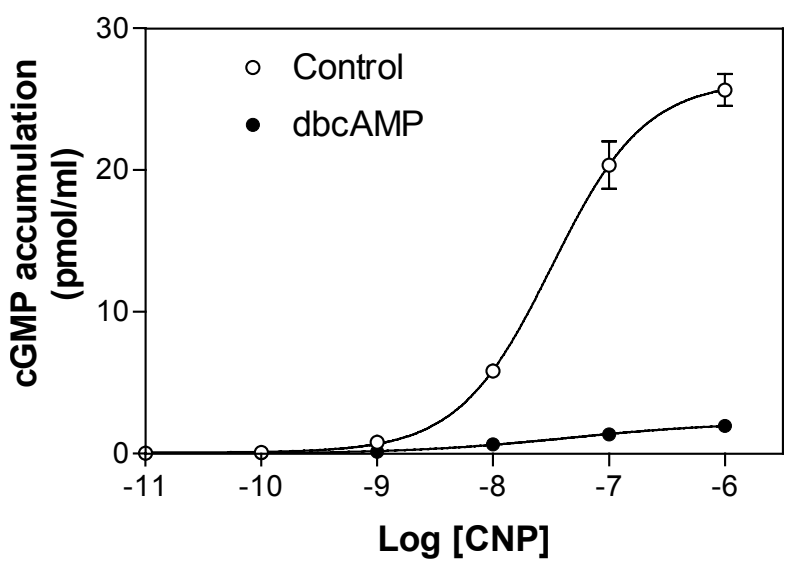

Figure 1 dbcAMP treatment suppresses CNP-stimulated cGMP formation in FRTL-5 cells. Confluent FRTL-5 cells grown in TSH-free $(5 \mathrm{H})$ medium for at least 4 days received either control $(5 \mathrm{H})$, or $5 \mathrm{H}$ medium containing $1 \mathrm{mM}$ dbcAMP for an additional 4 days, followed by determination of intracellular cGMP in the presence of $0.5 \mathrm{mM} \mathrm{IBMX}$ and increasing concentrations of CNP as described in Materials and Methods. Values are the means \pm S.E.M. of four separate wells. These data represent a single experiment performed twice with similar results.

cyclase/cAMP pathway represents the principal mechanism underlying the reduction of NPR-B activity by TSH in the FRTL-5 cell.

To characterize the time-course of the inhibition of NPR-B activity by cAMP, confluent cultures of FRTL-5 cells equilibrated in $5 \mathrm{H}$ medium for at least 4 days received either fresh control $(5 \mathrm{H})$ medium or $5 \mathrm{H}$ medium containing $1 \mathrm{mM}$ dbcAMP for 10, 20, and $40 \mathrm{~min}$ and 1, 3, and $6 \mathrm{~h}$ prior to stimulation with CNP and determination of intracellular cGMP (Fig. 2A). Results showed that following a transient increase peaking at $40 \mathrm{~min}$ of dbcAMP treatment, CNP-stimulated cGMP production fell significantly below control value after $6 \mathrm{~h}$ of exposure to the cAMP-mimetic. Figure 2B furthermore demonstrates that the suppression of NPR-B by dbcAMP increased to a maximal level following 1 day of treatment and continued unchanged through at least 4 days in the presence of dbcAMP. In FRTL-5 cultures equilibrated in medium $(6 \mathrm{H})$ containing $1 \mathrm{mIU} / \mathrm{ml}$ bovine TSH, replacement of this medium with $5 \mathrm{H}$ (i.e. removal of TSH) resulted in a time-dependent increase in CNP-stimulated cGMP that was first apparent at day 1 and continued to increase through 4 days in the TSH-free medium (Fig. 2C). In contrast, when $6 \mathrm{H}$ medium was replaced by medium containing $1 \mathrm{mM}$ dbcAMP, the low levels of CNPstimulated cGMP observed in the presence of TSH were maintained through the end of the study.

The dose-dependency of dbcAMP in inhibiting NPR-B activity in FRTL-5 cells is illustrated in Fig. 3. Treatment of cells for 1 day with increasing concentrations of dbcAMP resulted in a half-maximal reduction in CNP-stimulated cGMP production at a concen- tration of $0.2 \mathrm{mM}$ (Fig. 3), an inhibitory effect that was approximately the equivalent of $3.8 \mu \mathrm{IU} / \mathrm{ml}$ bovine $\mathrm{TSH}$ administered for the same length of time (data not shown).

\section{cAMP reduction of NPR-B activity is protein kinase $A$} (PKA) independent

Activation of PKA represents a principal downstream pathway for cAMP signaling in the mammalian cell, and in FRTL-5 cells has been equated with most of the effects of this cyclic nucleotide on thyroid-specific function. In the present study, we employed the specific inhibitors KT5720 and H-89 to assess the role of PKA activation in the cAMP-induced inhibition of NPR-B activity. FRTL-5 cells equilibrated in $5 \mathrm{H}$ medium were preincubated with either KT-5720 $(5 \mu \mathrm{M})$ or $\mathrm{H}-89(1$ and $30 \mu \mathrm{M})$ for $1 \mathrm{~h}$ prior to the addition of medium containing $2 \mathrm{mM}$ dbcAMP (1 $\mathrm{mM}$ final concentration) and incubation for an additional $24 \mathrm{~h}$. Appropriate controls received only $5 \mathrm{H}$ medium containing vehicle (dimethyl sulfoxide; DMSO). Results (Fig. 4) showed that neither KT-5720 nor H-89 reversed the inhibition of NPR-B induced by dbcAMP, on the contrary further inhibiting this activity by a slight, but significant degree. In addition, H-89 treatment by itself was sufficient to induce a marked decrease in NPR-B activity. These data provide strong evidence that the cAMP pathway leading to inhibition of CNPstimulated cGMP in FRTL-5 cells bypasses the PKA cascade to follow an alternate route to the inhibition of NPR-B activity.

\section{Effects of protein kinase $C$ (PKC) and calcium on NPR-B activity}

A conceivable scenario leading from cAMP generation to NPR-B inhibition could involve activation of PKC as several reports have cited the ability of PKC to desensitize NPR receptors (NPR-A and NPR-B) either by receptor dephosphorylation or a reduction in CNP binding affinity. To examine the potential role of PKC in the downregulation of NPR-B activity by cAMP, we studied both the short-term (30 min) and long-term $(24 \mathrm{~h})$ effects of the PKC activator PMA on CNP-stimulated cGMP accumulation in FRTL-5 cells. Figure 5A shows that PMA treatment for 30 min induced a rightward shift in CNPstimulated cGMP generation, consistent with a reduction in receptor affinity but not with a reduction in total active receptor as suggested by the dbcAMP data. Moreover, long-term $(24 \mathrm{~h})$ exposure to $1 \mu \mathrm{M}$ PMA, unlike cAMP exposure for the same duration, failed to produce any change in either receptor affinity or maximal activity compared with control (Fig. 5B).

Recently, another mechanism leading to NPR-B desensitization has been described which links an inhibition of NPR-B activity in a smooth muscle cell line to 
elevations in intracellular calcium. To determine whether increased intracellular calcium can induce the downregulation of NPR-B in FRTL-5 cells, confluent cultures equilibrated in $5 \mathrm{H}$ medium were exposed to medium containing $50 \mu \mathrm{M}$ of the calcium ionophore A23187 for $24 \mathrm{~h}$ after which dose-related CNP-stimulated cGMP production was compared with control cultures receiving only vehicle. Figure 5C shows that A23187 treatment
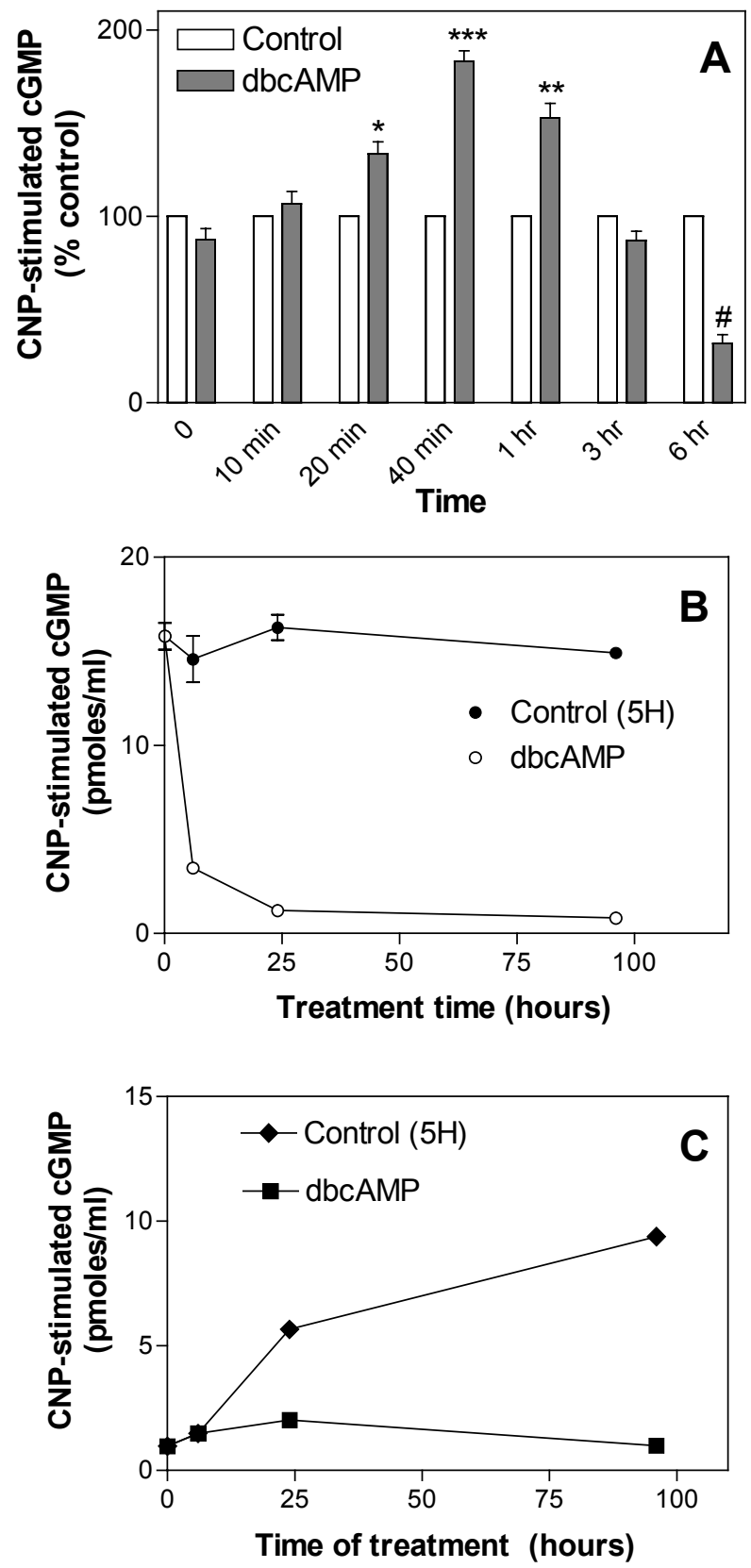

www.endocrinology.org

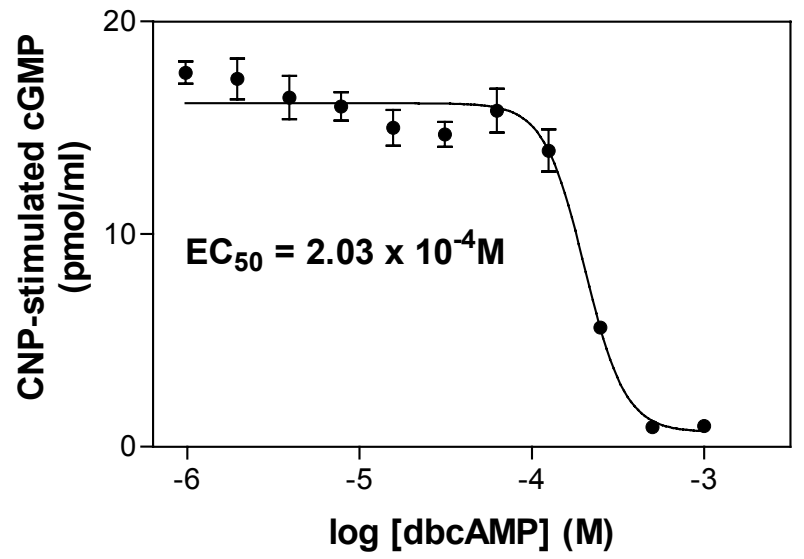

Figure 3 Concentration dependence of inhibition of CNP-stimulated cGMP accumulation in FRTL- 5 cells by dbcAMP. Confluent FRTL-5 cells grown in TSH-free $(5 \mathrm{H})$ medium for at least 4 days received dbcAMP for $24 \mathrm{~h}$ at various concentrations in $5 \mathrm{H}$ medium ranging from 0 to $1 \mathrm{mM}$, followed by determination of intracellular CGMP in the presence of $0.5 \mathrm{mM}$ IBMX and increasing concentrations of CNP as described in Materials and Methods. Values are the means \pm S.E.M. of three separate wells.

resulted in an approximately 3 -fold reduction in maximal CNP-stimulated cGMP without significantly affecting $\mathrm{EC}_{50}\left(\mathrm{EC}_{50}\right.$ control, $\left.32 \mathrm{nM} ; \mathrm{EC}_{50} \mathrm{~A} 23187,25 \mathrm{nM}\right)$.

\section{Involvement of calcium in the $d b c A M P$ inhibition of NPR-B} activity

Since A23187 produced reductions in CNP-stimulated cGMP that were qualitatively similar to those caused by dbcAMP, it was of interest to examine the role of calcium

Figure 2 Time-course of dbcAMP-stimulated cGMP formation in FRTL-5 cells. (A) Inhibitory effect of dbcAMP on CNP-stimulated cGMP formation requires $6 \mathrm{~h}$. Confluent FRTL- 5 cells grown in $5 \mathrm{H}$ medium for at least 4 days received either fresh $5 \mathrm{H}$ medium (control) or $5 \mathrm{H}$ medium containing $1 \mathrm{mM}$ dbcAMP and were incubated at $37^{\circ} \mathrm{C}$ for 10,20 , and $40 \mathrm{~min}$ and 1,3 , and $6 \mathrm{~h}$, followed by determination of intracellular cGMP in the presence of $0.5 \mu \mathrm{M}$ CNP and $0.5 \mathrm{mM}$ IBMX for $20 \mathrm{~min}$ as described in Materials and Methods. ${ }^{*} P<0 \cdot 05,{ }^{* *} P<0 \cdot 01, \# P<0 \cdot 001$, $* * * P<0.0001$ versus respective control by two-tailed $t$-test. (B) Inhibition of CNP-stimulated cGMP by dbcAMP is sustained through 4 days of incubation. Confluent FRTL-5 cells grown in $5 \mathrm{H}$ medium for at least 4 days received either fresh $5 \mathrm{H}$ medium (control) or $5 \mathrm{H}$ containing $1 \mathrm{mM}$ dbcAMP and were incubated at $37^{\circ} \mathrm{C}$ for $6 \mathrm{~h}, 1$ day, and 4 days followed by the determination of intracellular cGMP in the presence of $0.5 \mu \mathrm{M} \mathrm{CNP}$ and $0.5 \mathrm{mM}$ IBMX for 20 min. (C) Suppression of CNP-stimulated cGMP by TSH is ended by removal of TSH from the medium, but sustained by the addition of $1 \mathrm{mM}$ dbcAMP. FRTL-5 cells were grown to confluence in $6 \mathrm{H}$ medium in 24 -well plates, and medium was replaced with either $5 \mathrm{H}$ medium, or $5 \mathrm{H}$ medium containing $1 \mathrm{mM}$ dbcAMP for 6 h, 1 day, and 4 days followed by the determination of intracellular cGMP in the presence of $1 \mu \mathrm{M} \mathrm{CNP}$ and $0.5 \mathrm{mM}$ IBMX for 20 min. Values are means \pm S.E.M. 


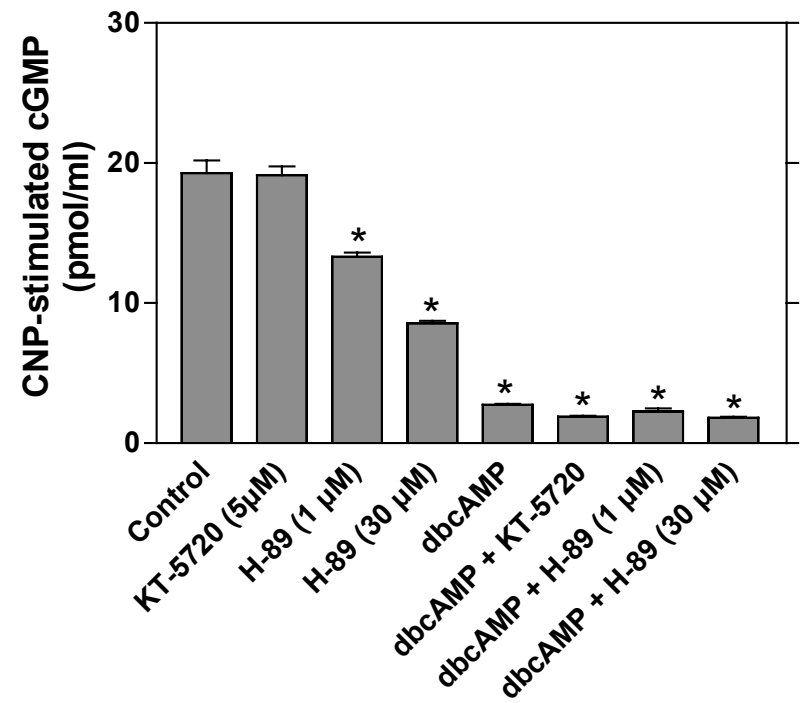

Figure 4 Inhibition of CNP-stimulated cGMP production by dbcAMP in FRTL-5 cells is PKA independent. Confluent cultures of FRTL-5 cells in $5 \mathrm{H}$ medium for at least 4 days before assay received $5 \mathrm{H}$ medium containing the PKA inhibitors, KT-5720 $(5 \mu \mathrm{M})$ and $\mathrm{H}-89(1$ and $30 \mu \mathrm{M})$, or the appropriate controls containing only DMSO vehicle for 30 min prior to the addition of either $5 \mathrm{H}$ medium, or $5 \mathrm{H}$ medium containing $2 \mathrm{mM}$ dbcAMP. Following an additional 6-h incubation at $37^{\circ} \mathrm{C}$, treatment medium was aspirated, and intracellular cGMP content in the presence of $0.5 \mathrm{mM}$ IBMX and $0.5 \mu \mathrm{M}$ CNP was determined as described in Materials and Methods. Values are the means \pm S.E.M. of four separate wells. This experiment was performed twice with similar results. ${ }^{*} P<0 \cdot 001$ compared with control.

ion in the cAMP-induced decrease in NPR-B activity. The specific requirement for intracellular calcium in the cAMP-induced inhibition of NPR-B activity was assessed using the cell-permeable calcium chelator BAPTA-AM to inhibit elevations in free calcium. Confluent cultures equilibrated in $5 \mathrm{H}$ medium received medium containing either BAPTA-AM $(75 \mu \mathrm{M})$ or vehicle (DMSO) for $30 \mathrm{~min}$, followed by the addition of an equal volume of $5 \mathrm{H}$ containing either $2 \mathrm{mM}$ dbcAMP or $5 \mathrm{H}$ only and incubation for an additional $6 \mathrm{~h}$. The results of a CNPstimulated cGMP assay performed following the 6-h incubation are shown in Fig. 6. As observed previously, dbcAMP treatment alone significantly reduced CNPstimulated cGMP to about $25 \%$ of control. BAPTA-AM pretreatment alone also significantly reduced NPR-B activity from its control value, although to a lesser extent than dbcAMP alone. However, when cells were preincubated with calcium chelator before receiving dbcAMP, the inhibitory effect of cAMP on NPR-B activity was completely abrogated and CNP-stimulated cGMP levels equaled those of cells receiving BAPTA-AM alone. These data strongly suggested that CAMP-induced inhibition of NPR-B activity in FRTL-5 cells is a calcium-dependent process.
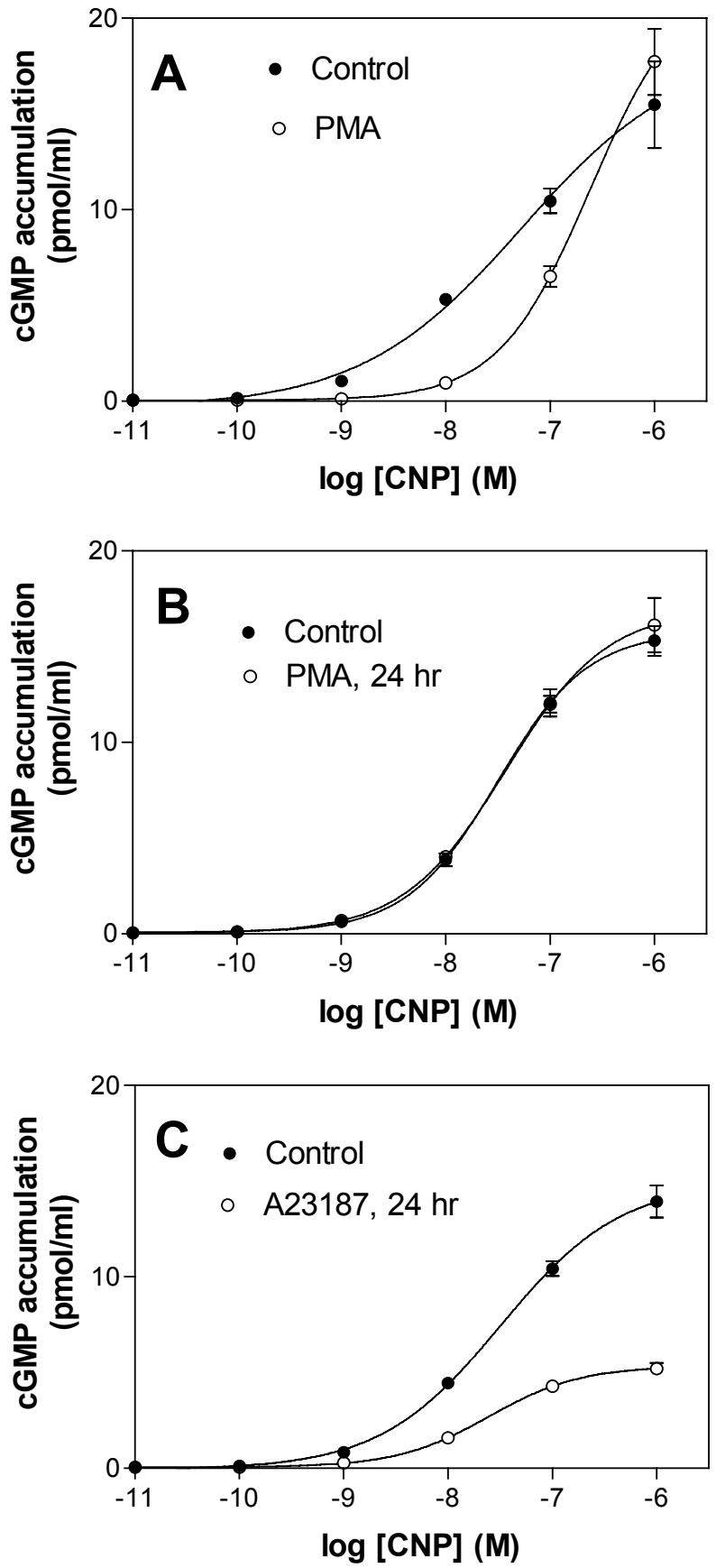

Figure 5 The calcium ionophore A23187, but not PMA reduces maximal levels of CNP-stimulated cGMP in FRTL-5 cells. Confluent FRTL-5 cells in 24-well plates in $5 \mathrm{H}$ medium for at least 4 days prior to assay received PMA (200 $\mathrm{nM}$ ) for (A) $30 \mathrm{~min}$ and (B) $24 \mathrm{~h}$, and $(\mathrm{C}) \mathrm{A} 23187(50 \mu \mathrm{M})$ for $24 \mathrm{~h}$, followed by stimulation with increasing concentrations of CNP in the presence of $0.5 \mathrm{mM}$ IBMX and determination of intracellular CGMP as described in Materials and Methods. Control plates performed in parallel with each treatment received only DMSO, followed by determination of CNP-stimulated cGMP. Values are means \pm S.E.M. 


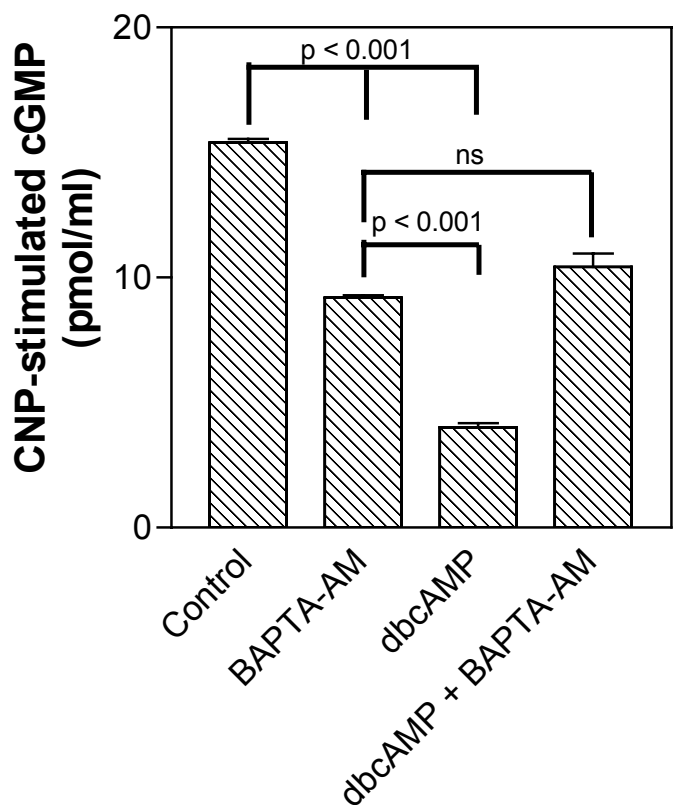

Figure 6 The dbcAMP-mediated inhibition of NPR-B activity is dependent upon intracellular calcium. FRTL-5 cells were grown to confluence in $6 \mathrm{H}$ medium in 24-well plates and medium was switched to $5 \mathrm{H}$ for at least 4 days. At assay, medium was replaced with either (1) $75 \mu \mathrm{M}$ BAPTA-AM (in DMSO vehicle) in $5 \mathrm{H}$ medium, or (2) $5 \mathrm{H}$ medium containing an equivalent concentration of DMSO (control) for 30 min prior to the addition of either $5 \mathrm{H}$ medium or $5 \mathrm{H}$ with $2 \mathrm{mM}$ dbcAMP for an additional $6 \mathrm{~h}$ at $37^{\circ} \mathrm{C}$. The four treatment groups thus established were

(1) control (5H only), (2) BAPTA-AM, (3) dbcAMP, and (4) dbcAMP+BAPTA-AM. Following treatment, cGMP production in the presence of $0.5 \mathrm{mM}$ IBMX and $0.5 \mu \mathrm{M}$ CNP was determined in each group. Values shown represent the means \pm S.E.M. of six separate wells from a single representative experiment performed three times.

\section{cAMP reduces NPR-B transcript levels in FRTL-5 cells}

We have noted in an earlier study (Sellitti \& Doi, 1999) that relative NPR-B transcript levels were decreased in FRTL-5 cells receiving TSH for a 4-day period. To test whether dbcAMP has a similar effect on NPR-B transcript levels, NPR-B expression was determined by real-time PCR in control cultures and in cells receiving $1 \mathrm{mM}$ dbcAMP for 3, 6, and $24 \mathrm{~h}$ (Fig. 7). Results showed no significant difference in NPR-B transcript levels between the control and cAMP-activated cells at either 3 or $6 \mathrm{~h}$ of treatment. However, after $24 \mathrm{~h}$ of dbcAMP, NPR-B transcript levels were significantly reduced to $40 \%$ of control value.

\section{TSH and CAMP increase immunoreactive CNP in FRTL-5 cells}

Although less direct than the modulation of NPR-B expression or activity as assessed in the studies above, regulation of the principal NPR-B ligand, CNP, could constitute another avenue through which cAMP can control the function of NPR-B in a natriuretic peptide system. In a previous study (Sellitti \& Doi, 1999), we showed that FRTL-5 cells contain transcripts encoding CNP-22, and that levels of these transcripts are upregulated in the presence of TSH. In the present study, we examined the effects of both TSH and dbcAMP on protein levels of CNP in these cells using an indirect immunofluorescence technique. Figure 8 establishes for the first time the presence of immunoreactive CNP protein in the FRTL-5 thyroid cells and illustrates moreover that expression of immunoreactive CNP in FRTL-5 is dependent upon the presence of TSH in the medium. Whereas cells continuously incubated in $6 \mathrm{H}(\mathrm{TSH})$ medium express high levels of cytoplasmic CNP staining (Fig. 8A), withdrawal of TSH for 3 days allows CNP staining to fall to levels approaching background (Fig. 8B). However, in a separate study, when $6 \mathrm{H}$ medium was replaced with $5 \mathrm{H}$ medium containing $1 \mathrm{mM}$ dbcAMP for 3 days, a high level of cytoplasmic CNP staining was maintained (Fig. $8 \mathrm{C})$. In contrast, cells receiving $5 \mathrm{H}$ medium during this time expressed little CNP (Fig. 8D). The dependence of CNP expression upon the presence of either TSH or dbcAMP in the medium resembled that of thyroglobulin, which was present at a high level in cells receiving dbcAMP for 3 days (Fig. 8E), but markedly reduced in cells grown in control medium $(5 \mathrm{H})$ (Fig. $8 \mathrm{~F}$ ).

Using real-time PCR we examined whether these cAMP-dependent changes in immunoreactive CNP are reflected in altered CNP transcript levels. Figure 9 shows that dbcAMP markedly up-regulates CNP transcript levels in FRTL-5 cells to approximately 5-fold control within only $3 \mathrm{~h}$ post-treatment, increasing to $15 \cdot 4-$ and $8 \cdot 8$-fold control values at $6 \mathrm{~h}$ and $24 \mathrm{~h}$ respectively.

\section{Discussion}

Natriuretic peptide systems consisting of the NPR-B and its principal ligand CNP have been identified in several organs and cell types, where they constitute a mechanism for the autocrine or paracrine generation of an intracellular cGMP signal (Silberbach \& Roberts 2001). The physiologic importance of such a system is perhaps best appreciated in the vasculature, where the actions of cGMP generated by NPR-B activation essentially parallel those of cGMP generated by activation by $\mathrm{NO}$ of soluble guanylyl cyclase in inducing vasorelaxation and inhibiting smooth muscle proliferation (Itoh et al. 1997). To date much of the emphasis on the regulation of vascular natriuretic peptide systems (Abbey \& Potter 2002) and natriuretic peptide systems in other organs (Crook \& Chang 1997, Fowkes et al. 2000) has centered upon those hormones (vasopressin, angiotensin II, and gonadotropinreleasing hormone) that stimulate the phospholipase $\mathrm{C}$ signaling pathway to activate intracellular PKC. Support for other intracellular signaling pathways leading to 


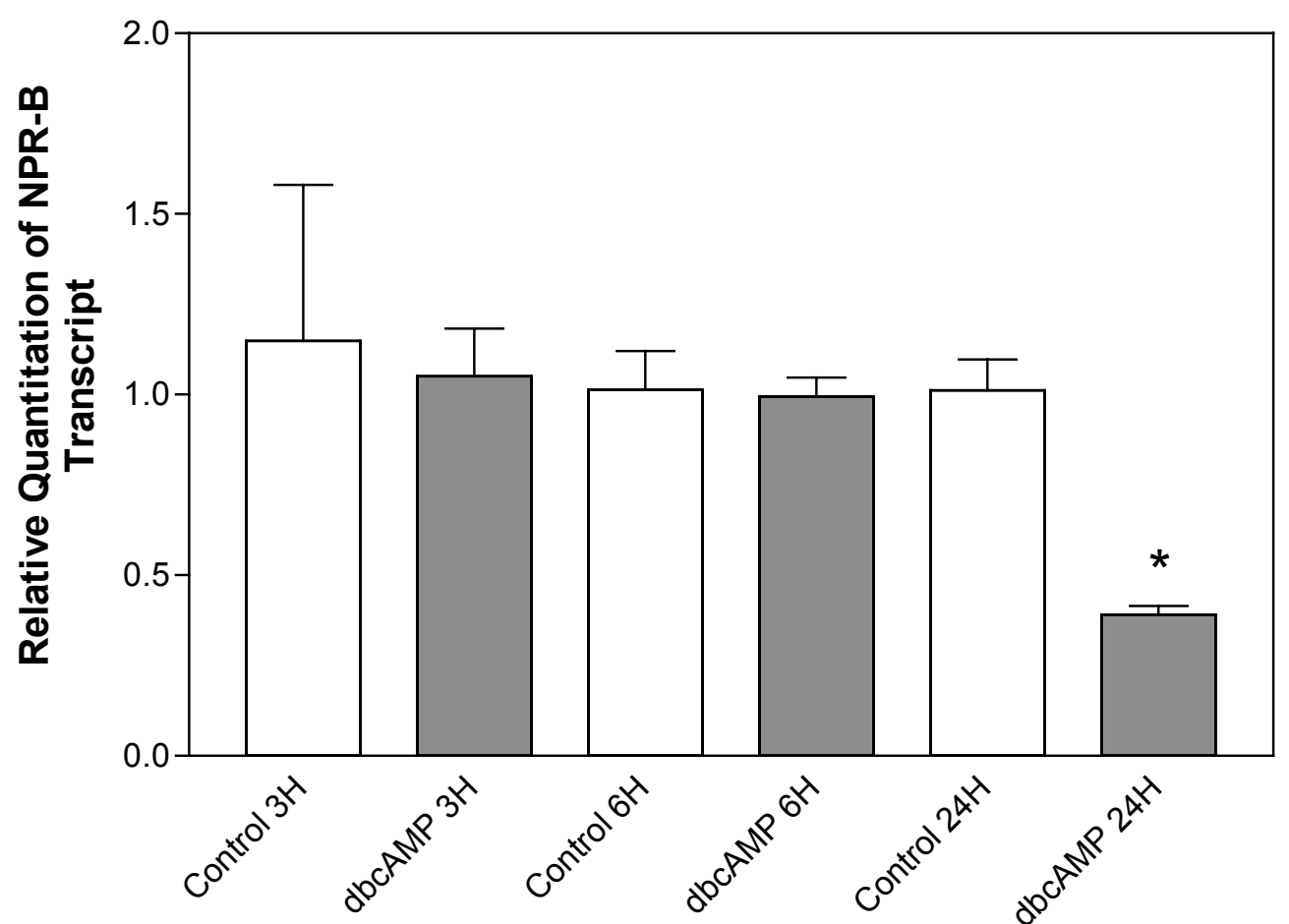

Figure 7 Effect of dbcAMP on NPR-B transcript levels. FRTL-5 cells were plated into 6-well plastic cluster plates in $6 \mathrm{H}$ medium, then washed and incubated in $5 \mathrm{H}$ for at least 4 days. After exposure to either $1 \mathrm{mM}$ dbcAMP or control $(5 \mathrm{H})$ medium for an additional 3, 6, or $24 \mathrm{~h}$, total RNA was extracted and relative quantitation of NPR-B transcript levels was performed using real-time PCR as described in Materials and Methods. Data bars for each time-point represent the mean \pm S.E.M. of NPR-B transcript levels in dbcAMP-treated cells normalized to its respective control using the comparative Ct method. ${ }^{*} P<0 \cdot 001$ vs respective control by unpaired $t$-test.

NPR-B regulation has been less conclusive. For example, various authors have cited either no effect (McArdle et al. 1993), or an inhibitory effect (Guidone et al. 2002) of pituitary adenylate cyclase activating polypeptide (PACAP) or other activators of the adenylyl cyclase/ cAMP-signaling pathway on NPR-B activity.

In our studies with the FRTL-5 rat thyroid-derived cell line, we had shown that long-term incubation with TSH, the principal hormonal regulator of thyroid function, induces a significant reduction in CNP-stimulated cGMP, indicating either a desensitization or down-regulation of NPR-B by the thyrotropic hormone (Sellitti \& Doi 1999). As most of the activity of TSH in the FRTL- 5 cells has been tied to its activation of the adenylyl cyclase/cAMP signaling pathway, we speculated that generation of a cAMP signal represents a key mechanism for inactivation of NPR-B activity in this cell line. In the present study, we sought to delineate such a pathway by examining the role of the soluble cAMP mimetic, dbcAMP, in the regulation of CNP-stimulated cGMP production in FRTL-5 cells. We have shown (1) that dbcAMP alone is sufficient to account for the previously observed reduction of NPR-B activity in the presence of TSH; (2) that the
NPR-B inhibitory pathway is independent of PKA; (3) that the mechanism leading from cAMP to inhibition of NPR-B is dependent upon intracellular calcium; and (4) in the face of a reduction in NPR-B activity by cAMP, the expression of its principal ligand CNP is increased. Taken together, these results indicate the potential for a significant role for hormones coupled to Gs/adenylyl cyclase in the regulation of NPR-B/CNP natriuretic peptide systems.

Although the pathway leading from dbcAMP to the reduction of NPR-B activity remains to be defined, it is clear that it is independent of PKA activation since preincubation with either of two inhibitors of PKA, KT5720 and H89, failed to block even partially the reduction of CNP-stimulated cGMP following treatment with dbcAMP. On the contrary, one of these PKA inhibitors, H-89, exhibited a dose-related reduction in NPR-B activity in the absence of dbcAMP, an effect possibly related to the inhibitory actions of this compound on other enzymatic activities. Moreover, the presence of the general phosphodiesterase inhibitor IBMX in all of the CNP-stimulated cGMP assays eliminates the likelihood of an activation by dbcAMP of cGMP phosphodiesterase as 

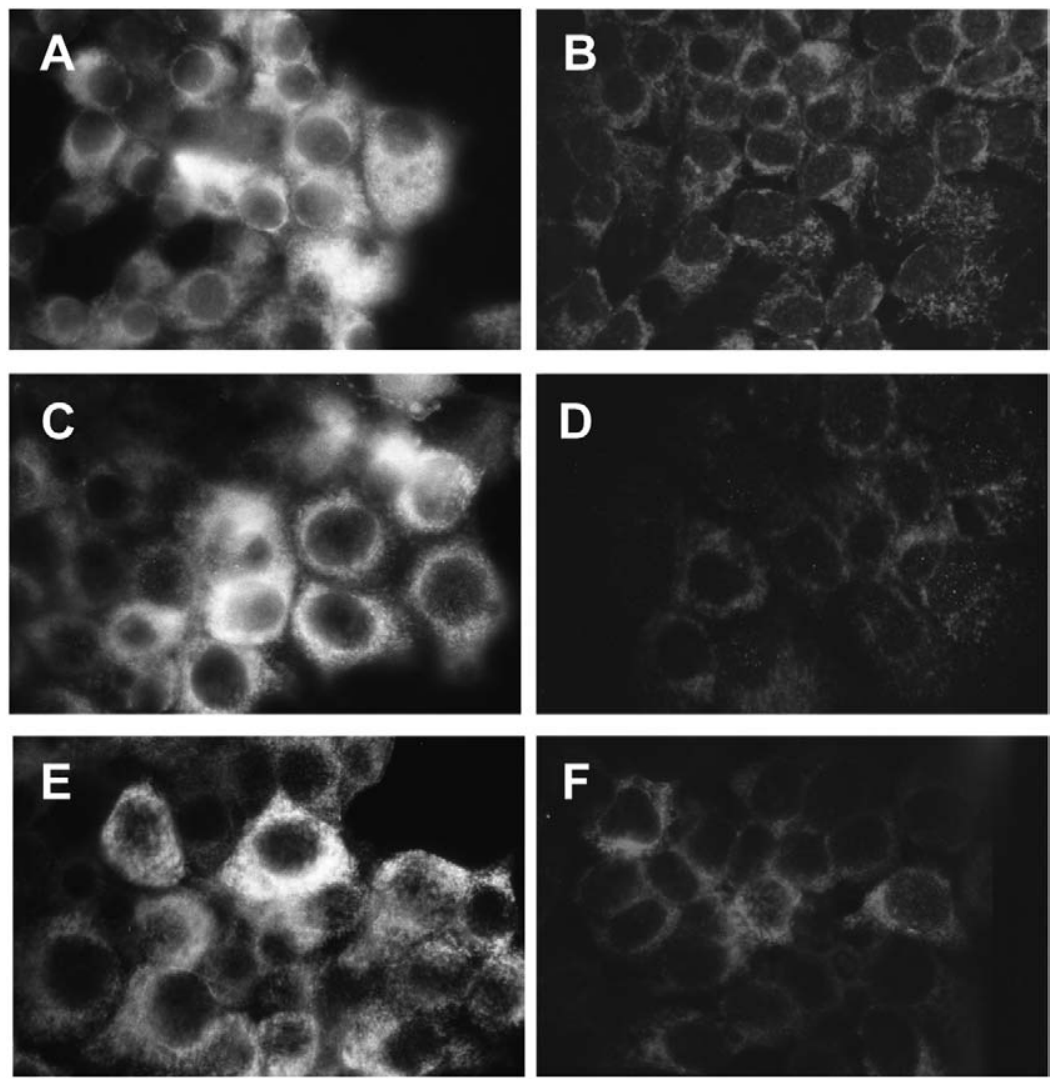

Figure $8 \mathrm{TSH}$ and dbcAMP increase the expression of immunoreactive CNP in FRTL-5 cells. FRTL-5 cells were plated onto glass coverslips in $6 \mathrm{H}$ medium and 1 day later received either $6 \mathrm{H}$ or $5 \mathrm{H}$ medium for an additional 3 days before fixing the cells and staining with polyclonal anti-CNP. (A) Cells in $6 \mathrm{H}$ medium for 3 days stained with anti-CNP and (B) cells in $5 \mathrm{H}$ medium stained with anti-CNP. In another study (C-E), FRTL-5 cells were plated onto glass coverslips in $6 \mathrm{H}$ medium and after 1 day received either $5 \mathrm{H}$ medium (control) or $5 \mathrm{H}$ medium containing $1 \mathrm{mM}$ dbcAMP for an additional 3 days before fixing the cells and staining with either anti-CNP or anti-Tg. (C) Cells in $5 \mathrm{H}$ medium with $1 \mathrm{mM}$ dbcAMP for 3 days stained with anti-CNP; (D) cells in $5 \mathrm{H}$ medium (control) for 3 days stained with anti-CNP; (E) cells in $5 \mathrm{H}$ medium with $1 \mathrm{mM}$ dbcAMP for 3 days stained with anti-Tg; and (F) cells in $5 \mathrm{H}$ medium for 3 days stained with anti-Tg. Controls for each study included cells receiving no primary antibody (data not shown).

an explanation for our data. Alternative pathways of cAMP action leading to inactivation of NPR-B in the FRTL-5 cell could include activation of cyclic nucleotide-gated ion channels, direct modulation of the mitogen-activated protein kinase pathway via activation of the exchange protein directly activated by cAMP (Epac) or activation or inhibition of the phosphatidyl-inositol 3 (PI-3) kinase pathway (Kim et al. 2001, Saavedra et al. 2002). However, in the present study, preincubation of FRTL-5 cells with either the mitogen-activated protein kinase kinase (MEK) inhibitor PD98059, or the PI-3 kinase inhibitor LY294002 had no effect on the inhibitory effect of dbcAMP on CNP-induced cGMP accumulation (data not shown). In addition, activation of PKC by treatment with PMA for $30 \mathrm{~min}$ caused a rightward shift in the dose- related CNP stimulation of cGMP in FRTL-5 cells, yet caused no clear change in the maximal level of cGMP produced, and a 24-h exposure to the same dose of PMA, which would be expected to down-regulate PKC activity, had no effect on subsequent CNP-stimulated cGMP production. Only A23187 was capable of inhibiting NPR-B activity in this study, presumably as a consequence of an ionophore-induced increase in intracellular calcium. Although A23187 and dbcAMP produced qualitatively similar changes in CNP-induced cGMP production in this study, we have not however examined the effects of dbcAMP on intracellular calcium in FRTL-5 cells. Tornquist \& Ahlstrom (1993) have studied the modulatory effect of cAMP on calcium fluxes in FRTL-5 cells and found that preincubation of these cells with 


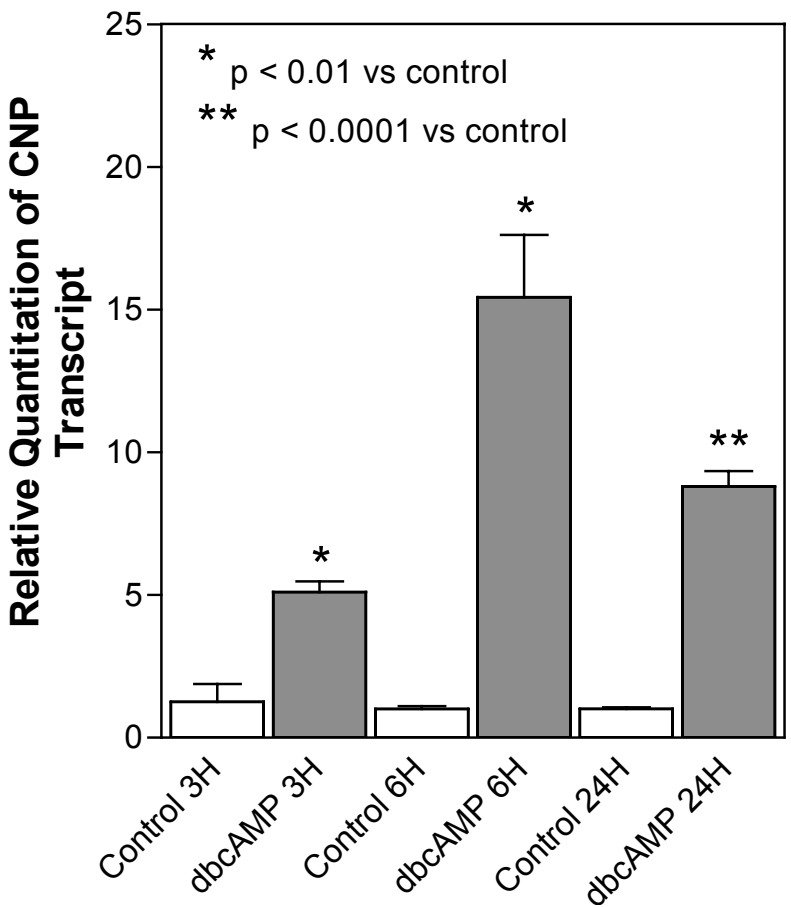

Figure 9 Effect of dbcAMP on CNP transcript levels. FRTL-5 cells were plated into 6 -well cluster plates in $6 \mathrm{H}$ medium, then washed and incubated in $5 \mathrm{H}$ for at least 4 days. After exposure to either $1 \mathrm{mM}$ dbcAMP or control $(5 \mathrm{H})$ medium for an additional 3,6 , or $24 \mathrm{~h}$, total RNA was extracted and relative quantitation of CNP transcript levels was performed using real-time PCR as described in Materials and Methods. Data bars for each time-point represent the means \pm S.E.M. of CNP transcript levels in dbcAMP-treated cells normalized to its respective control using the comparative $\mathrm{Ct}$ method.

$1 \mathrm{mM}$ dbcAMP attenuated ATP-induced $\mathrm{Ca}^{2+}$ influx for at least $30 \mathrm{~min}$, but the influence of a sustained $(6-24 \mathrm{~h})$ cAMP stimulation on $\mathrm{Ca}^{2+}$ flux in this cell line has not been determined. Nonetheless, our finding that the cAMP effect was completely abolished by preincubation with the cell-permeable calcium chelator BAPTA-AM makes it clear that the cAMP regulation of NPR-B is a calciumdependent process. Abbey \& Potter (2002) have recently used this chelator to show that elevation in intracellular calcium, rather than activation of $\mathrm{PKC}$, represents an important mechanism for NPR-B inhibition in smooth muscle cells induced by pressor hormones such as arginine vasopressin and angiotensin II.

In contrast to previous reports showing a desensitization of NPR-B activity within only minutes of hormonal treatment, our present studies with dbcAMP in FRTL-5 indicate that an interval of between 3 to $6 \mathrm{~h}$ is required for the cyclic nucleotide to reduce CNP-stimulated cGMP compared with control, after which NPR-B activity remains suppressed for at least 4 days in the continued presence of dbcAMP. The absence of a rapid effect of dbcAMP on NPR-B activity, as opposed to the heterologous desensitization of the receptor by modification of the receptor/enzyme, could suggest that cAMP affects NPR-B in FRTL-5 cells by a different mechanism such as transcriptional down-regulation (Kishimoto 1994) or receptor internalization and degradation (Pandey et al. 2002). In the present study, however, we were unable to show an effect of dbcAMP on NPR-B transcript levels at a time $(6 \mathrm{~h})$ and dose that resulted in a marked decrease in CNP-stimulated cGMP. Nonetheless, after a 24-h treatment with dbcAMP, NPR-B transcript levels were reduced to only $40 \%$ of control values, suggesting that transcriptional down-regulation by cAMP could contribute to the sustained reduction of NPR-B activity through 4 days of dbcAMP treatment. These results suggested that cAMP is the likely mediator of the TSH-induced downregulation of NPR-B transcript that we had observed earlier in FRTL-5 cells (Sellitti \& Doi 1999).

Finally, since in most tissues where it has been identified, NPR-B is known to constitute part of a natriuretic peptide system acting in concert with its locally produced ligand CNP, we were interested in identifying CNP in the FRTL-5 cell and assessing its regulation by cAMP. Our results demonstrated the presence of immunoreactive CNP in this rat thyroid-derived cell line, confirming what we had earlier inferred from the presence of CNP transcript in both this rat thyroid-derived cell line and in rat thyroid per se (Sellitti \& Doi 1999). The present data also showed that the production of immunoreactive CNP in FRTL-5 cells is dependent upon stimulation with either dbcAMP or TSH, since in the absence of both of these factors cytoplasmic immunoreactive CNP was negligible. In addition, we have shown here, using real-time PCR, that dbcAMP induces a significant up-regulation of CNP transcript as early as $3 \mathrm{~h}$ after treatment which is sustained at a high level (>8-fold control) for at least $24 \mathrm{~h}$, suggesting that the cAMP-induced increase in immunoreactive CNP originates at the level of gene transcription. Other members of the natriuretic peptide family have been shown to respond to cAMP with increased transcriptional activity (He et al. 2000) and, in the case of brain natriuretic peptide (BNP) in human myocytes, cAMP has been shown to target regulatory elements in the proximal BNP promoter using a PKA-independent pathway. However, this is the first evidence to our knowledge for cAMP up-regulated CNP production.

A physiologic rationale for the co-ordinated upregulation of $\mathrm{CNP}$ and down-regulation of its cognate receptor by cAMP in the thyroid cell will require further investigation. It is possible that the primary purpose of $\mathrm{TSH} / \mathrm{cAMP}$ stimulation of CNP synthesis in vivo is to increase thyroidal blood flow to follicles undergoing TSH-induced increases in hormone synthetic activity. Coincident with the increased blood flow, suppression of NPR-B activity in the follicular cell by TSH/cAMP acting on both transcriptional and post-translational mechanisms could ensure the inhibition of cGMP- 
utilizing signaling pathways in the thyroid cell. Since several of the specific functions of cGMP in the thyroid cell identified thus far involve the inhibition of iodide uptake (Bocanera et al. 1997) and its organification (Costamagna et al. 1998), the suppression of NPR-B guanylyl cyclase activity by TSH/cAMP may be essential in the thyroid cell that is actively synthesizing thyroid hormone.

In summary, the present results demonstrate the regulation of the CNP/NPR-B natriuretic peptide system in the FRTL- 5 by intracellular cAMP. These studies suggest that, at least in the rat thyroid phenotype, cAMP reduces NPR-B activity via a calcium-dependent, PKAindependent mechanism and also via a reduction in NPR-B transcription. Whether NPR-B undergoes an identical down-regulation by cAMP in other cell types and when cAMP-linked hormones other than TSH are involved will require further investigation of the specific steps leading to receptor inactivation.

\section{Funding}

This work was supported by USUHS grant RO83MV.

\section{References}

Abbey SE \& Potter LR 2002 Vasopressin-dependent inhibition of the C-type natriuretic peptide receptor, NPR-B/GC-B, requires elevated intracellular calcium concentrations. Journal of Biological Chemistry 277 42423-42430.

Ambesi-Impiombato FS, Picone R \& Tramontano D 1982 Influence of hormones and serum on growth and differentiation of the thyroid cell strain FRTL. In Growth of Cells in Hormonally Defined Media, pp 102-123. Eds GF Sato, A Pardee \& DA Sirbasku. Cold Spring Harbor Symposium on Cell Proliferation, Cold Spring Harbor: Cold Spring Harbor Laboratory.

Anand-Srivastava MB \& Trachte GJ 1993 Atrial natriuretic factor receptors and signal transduction mechanisms. Pharmacological Reviews 45 455-497.

Bocanera LV, Krawiec L, Silberschmidt D, Pignataro O, Juvenal GJ, Pregliasco LB \& Pisarev MA 1997 Role of cyclic 3',5' guanosine monophosphate and nitric oxide in the regulation of iodide uptake in calf thyroid cells. Journal of Endocrinology 155 451-457.

Costamagna ME, Cabanillas AM, Coleoni AH, Pellizas CG \& Masini-Repiso AM 1998 Nitric oxide donors inhibit iodide transport and organification and induce morphological changes in cultured bovine thyroid cells. Thyroid 8 1127-1135.

Crook RB \& Chang AT 1997 Differential regulation of natriuretic peptide receptors on ciliary body epithelial cells. Biochemical Journal 324 49-55.

Flynn T 1997 The biochemistry of atrial natriuretic peptides. In Natriuretic Peptides in Health and Disease, pp 1-19. Eds WK Samson \& ER Levin. Totowa: Humana Press.

Fowkes RC, Forrest-Owen W \& McArdle CA 2000 C-type natriuretic peptide (CNP) effects in anterior pituitary cell lines: evidence for homologous desensitization of CNP-stimulated cGMP accumulation in a T3-gonadotroph-derived cell. Journal of Endocrinology 166 195-203.

Gardner DG, Wu J \& Kovacic-Milivojevic B 1997 Cellular and molecular aspects of the A-type natriuretic peptide. In Natriuretic Peptides in Health and Disease, pp 71-94. Eds WK Samson \& ER Levin. Totowa: Humana Press.
Guidone G, Muller D, Vogt K, Mukhopadhyay AK 2002 Characterization of VIP and PACAP receptors in cultured rat penis corpus cavernosum smooth muscle cells and their interaction with guanylate cyclase-B receptors. Regulatory Peptides 108 63-72.

He Q, Wu G \& Lapointe MC 2000 Isoproterenol and cAMP regulation of the human brain natriuretic peptide gene involves Src and Rac. American Journal of Physiology. Endocrinology and Metabolism 278 E1115-E1123.

Igaki T, Itoh H, Suga S, Hama N, Ogawa Y, Komatsu Y, Mukoyama M, Sugawara A, Yoshimasa T, Tanaka I \& Nakao K 1996 C-type natriuretic peptide in chronic renal failure and its actions in humans. Kidney International 55 (Suppl) S144-S147.

Itoh H, Suga S, Ogawa Y, Komatsu Y, Tamura N, Igaki T, Yamashita J, Doi K, Chun T-H, Inoue M et al. 1997 Cellular and molecular aspects of C-type natriuretic peptide (CNP). In Natriuretic Peptides in Health and Disease, pp 107-122. Eds WK Samson \& ER Levin. Totowa: Humana Press.

Kim S, Jee K, Kim D, Koh H \& Chung J 2001 Cyclic AMP inhibits Akt activity by blocking the membrane localization of PDK1. Journal of Biological Chemistry 276 12864-12870.

Kishimoto I, Yoshimasa T, Suga S, Ogawa Y, Komatsu Y, Nakagawa O, Itoh H \& Nakao K 1994 Natriuretic peptide clearance receptor is transcriptionally down-regulated by beta- 2 adrenergic stimulation in vascular smooth muscle cells. Journal of Biological Chemistry 269 28300-28308.

Levin ER 1993 Natriuretic peptide C-receptor: more than a clearance receptor. American Journal of Physiology 264 E483-E489.

McArdle CA, Poch A \& Kappler K 1993 Cyclic guanosine monophosphate production in the pituitary: stimulation by C-type natriuretic peptide and inhibition by gonadotropin-releasing hormone in aT3-1 cells. Endocrinology 132 2065-2072.

Noubani A, Farookhi R \& Gutkowska J 2000 B-type natriuretic peptide receptor expression and activity are hormonally regulated in rat ovarian cells. Endocrinology 141 551-559.

Pandey KN, Nguyen HT, Sharma GD, Shi S-J \& Kriegel AM 2002 Ligand-regulated internalization, trafficking, and down-regulation of guanylyl cyclase/atrial natriuretic peptide receptor-A in human embryonic kidney 293 cells. Journal of Biological Chemistry 277 $4618-4627$.

Papapetropoulos A, Marczin N, Mora G, Milici A, Murad F \& Catravas JD 1995 Regulation of vascular smooth muscle soluble guanylate cyclase activity, mRNA, and protein levels by cAMP-elevating agents. Hypertension 26 696-704.

Potter LR \& Hunter T 2000 Activation of protein kinase C stimulates the dephosphorylation of natriuretic peptide receptor-B at a single serine residue. A possible mechanism of heterologous desensitization. Journal of Biological Chemistry 275 31099-31106.

Potter LR \& Hunter T 2001 Guanylyl cyclase-linked natriuretic peptide receptors: structure and regulation. Journal of Biological Chemistry 276 6057-6060.

Rapoport B \& Spaulding SW 1996 Mechanism of action of thyrotropin and other thyroid growth factors. In Werner \& Ingbar's The Thyroid, A Fundamental and Clinical Text, pp 207-219. Eds LE Braverman \& RD Utiger. Philadelphia: Lippincott-Raven.

Saavedra AP, Tsygankova OM, Prendergast GV, Dworet JH, Cheng G, \& Meinkoth JL 2002 Role of cAMP, PKA and Rap1A in thyroid follicular cell survival. Oncogene 21 778-788.

Sellitti DF \& Doi SQ 1999 Regulation of natriuretic peptide receptors by thyrotropin in FRTL-5 rat thyroid cells: evidence for nonguanylate cyclase atrial natriuretic factor-binding sites in cells lacking the natriuretic peptide receptor C. Endocrinology 140 $1365-1374$.

Silberbach M \& Roberts CT 2001 Natriuretic peptide signaling. Molecular and cellular pathways to growth regulation. Cellular Signalling 13 221-231. 
Suga S, Nakao K, Itoh H, Komatsu Y, Ogawa Y, Hama N \& Imura H 1992 Endothelial production of C-type natriuretic peptide and its marked augmentation by transforming growth factor- $\mathrm{B}$ - possible existence of 'vascular natriuretic peptide system'. Journal of Clinical Investigation 90 1145-1149.

Tornquist K \& Ahlstrom M 1993 Modulatory effect of cyclic AMP on calcium fluxes in FRTL-5 cells. Journal of Cellular Physiology 157 625-630.

Yasoda A, Ogawa Y, Suda M, Tamura H, Mori K, Sakuma Y, Chusho H, Shiota K, Tanaka K \& Nakao K 1998 Natriuretic peptide regulation of endochondral ossification. Evidence for possible roles of the C-type natriuretic peptide/guanylyl cyclase-B pathway. Journal of Biological Chemistry 273 11695-11700.

Received in final form 4 September 2003 Accepted 26 September 2003 